\title{
Analysis of PSC gross split implementation in Russian offshore
}

\author{
M.I. Kiat, S.I. Iliukhin, A.Kh. Ozdoeva \\ Muhammadiksankiat95@gmail.com|savelykh@yandex.ru|4305@bk.ru \\ National Research University of Oil and Gas named after I.M. Gubkin, Moscow, Russian Federation
}

\begin{abstract}
Product Sharing Contract with Gross Split scheme come up as an alternative solution for developing a healthy, fair and sustainable international oil and gas cooperation in Russian offshore [1]. In the application, benefits will be optimal for all parties if all legal requirements and business interests are met. Regarding that, the monitoring process on PSC GS implementation is as crucial as the negotiation process in making suitable terms and conditions for both parties. However, the real problem is negotiation participants (representatives of parties) are not fully aware of all PSC elements, which causes long, uncertain, and repetitive discussion or even results in unfair domination of one party over another. This paper shows the design of the tree and expert analysis to help all parties understand PSC elements, sensitivities, and their interactions before entering negotiation process. The methodology used is a theoretical survey (analysis \& synthesis) based on world practices and Russian economical, technical, and geological characteristics. The result depicts both analyses are important materials to prepare all parties for the effective decision making process as well as support the establishment of win-win contract details.
\end{abstract}

Keywords: Production Sharing Contract (PSC), Gross Split (GS), Host-Government (HG), and International Oil Company (IOC).

\section{Introduction}

Since the date it's created in 2017, PSC with the new scheme started to implement in more than 42 working areas in Indonesia. The main differences of this hybrid of PSC and concession from others (basic ideas) are as follows: split starts from gross revenue; IOC takes 100\% responsibility of E\&P cost; and $\mathrm{HG}$ can increase/decrease IOC's share by assessing variable (every POD) and progressive components (monthly), design of which is based on existing oil and gas fields calibration. Facing difficulties to explore and develop its resources in certain complex field condition, Russia is obviously in need of applying PSC GS to increase its fiscal attractiveness. Because existing contracts don't have necessary functionality for efficient, simple, certain and transparent interaction with IOCs, while the international collaboration is significant due to the absence of sufficient technologies, facilities, human resources and investments [2]. After all, it's not the same PSC GS scheme to offer to implement in different countries, but the analogy of it by maintaining the basic ideas and adjusting the clauses, which are shown in table 1.

Table 1. PSC basic elements (clauses) [3-18]

\begin{tabular}{|c|c|c|}
\hline & National Legislation & Contract Negotiation \\
\hline Operational & Government & Work commitment; \\
Aspects & participation; & Relinquishment; \\
& Ownership transfer; & Commerciality \\
& Conflict resolution; & \\
Insurance & \\
\hline Revenue or & Royalties; Taxation; & Bonus payments; Cost \\
Production & Depreciation rates; & recovery limits; \\
Sharing & Investment credit; & Production sharing \\
Elements & Domestic Market; & \\
& Obligation; & \\
& Ringfencing & \\
\hline
\end{tabular}

It's undeniable that there are tendencies from both parties to dominate the contract. The negotiation trade-off between HG and IOCs lies in the clauses above. Thus, every party should analytically and statistically understand how the elements mean to control each bargain position. This is necessary to establish win-win solution contracts.

\section{Tree analysis}

Based on all PSC basic elements, decision tree analysis is presented in Fig. 1. The map shows the details of basic elements and possible options of their implementation. Considering a large number of different proposed contracts, the tree allows parties to fast and thoroughly understand how this or that project can be economically effective for all, which is certainly based on comprehensive analysis of their capacity, market conditions, and specific interests. It is worth noting that the assessment of possible solutions in this analysis allows you to determine a strategy for public-private partnership within the framework of commercial, budgetary, social, technological and environmental efficiency [19].

Referring to the map, onshore and Caspian offshore are not a prioritized option due to the fact that Russian companies are able to deal with those fields, except, shale and other unconventional fields, while offshore fields, which require more cost and technologies, are more challengeable. Therefore, by considering their most difficult circumstances the focus is on Sakhalin and Arctic.

\section{Expert's analysis}

Table 2 presents experts' opinion on each basic element according to survey using multi criterial analysis. The expert Council consisted of about 80 specialists in various fields of science, which allowed us to consolidate the information received and determine the most priority areas for analysis and evaluation. The experts score the level of significance of each criteria and set the rank based on their experiences and objectives. Besides, the table classifies general requirements that $\mathrm{HG}$ and $\mathrm{IOC}$ are likely to put forward during negotiations. 


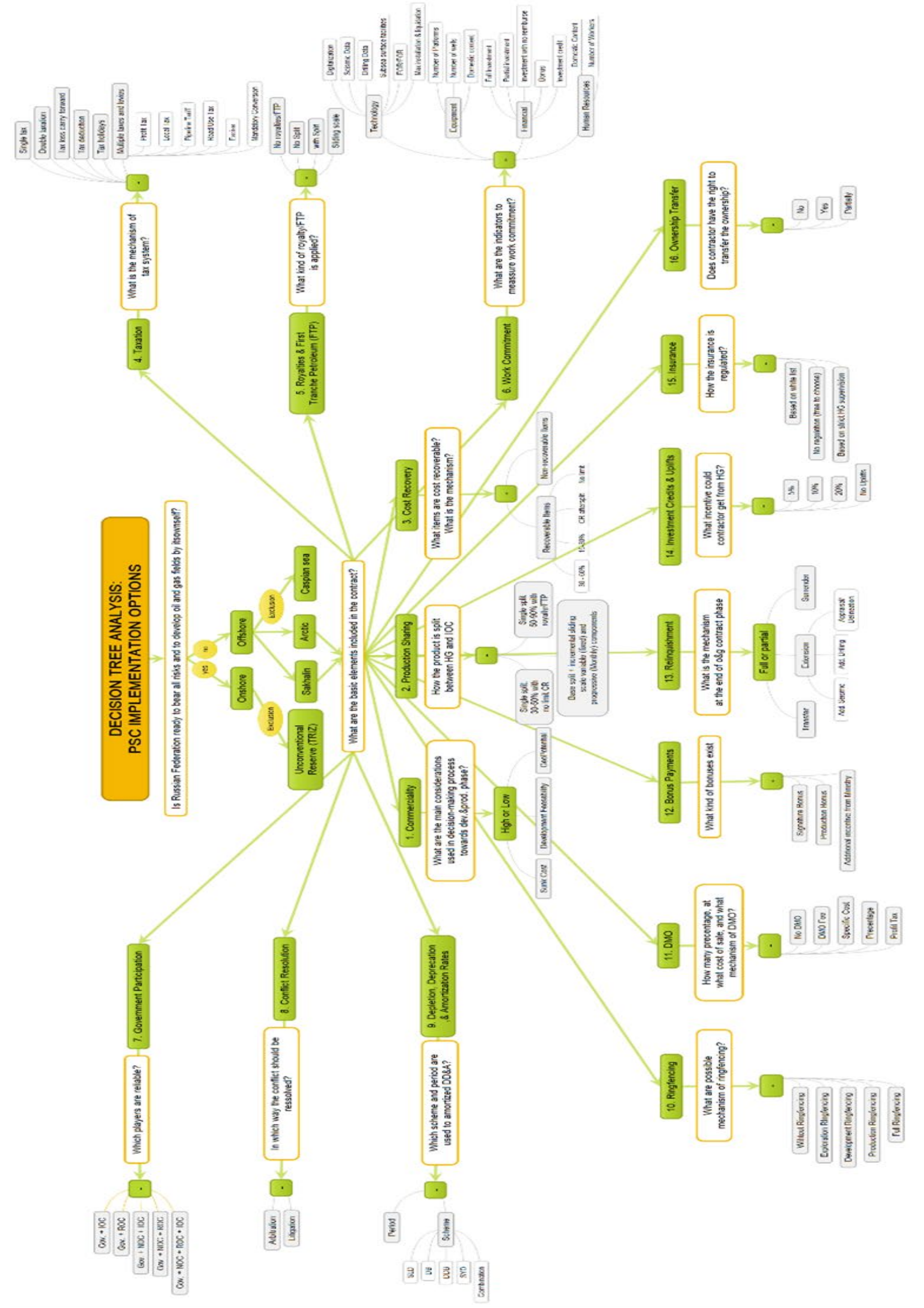

Fig. 1. Decision tree analysis (Created by Authors) 
Table 2. Expert analysis: PSC implementation option in Russian offshore (Created by Authors)

\begin{tabular}{|c|c|c|c|c|c|}
\hline Rank & Name & HG & IOC (Contractor) & PSC GS (Optimum) & Note \\
\hline 1 & Commerciality & \multicolumn{3}{|c|}{ Low sunk cost, high development feasibility, \& high geopotential. } & $\begin{array}{l}\text { Considering high risks in } \\
\text { exploration phase, Contractor tends } \\
\text { to recover sunk cost maximally. } \\
\text { Geopotential is the key to decide } \\
\text { whether field development is } \\
\text { feasible in high sunk cost. }\end{array}$ \\
\hline 2 & Product sharing & $\begin{array}{l}\text { Single split: } 50-90 \% \\
\text { share with high } \\
\text { royalty/FTP }\end{array}$ & $\begin{array}{c}\text { Single split: } 30-50 \% \\
\text { with no limit CR }\end{array}$ & $\begin{array}{l}\text { Base split + variable } \\
\text { (fixed) and progressive } \\
\text { (monthly) components }\end{array}$ & $\begin{array}{l}\text { Incremental sliding } \text { scale } \\
\text { production sharing guarantees } \\
\text { flexibility, fairness, simplicity, } \\
\text { transparency \& certainty of HG and } \\
\text { Contractor's share. }\end{array}$ \\
\hline 3 & Cost recovery & $\begin{array}{c}30-60 \% \text {, after } \\
\text { recovering capital cost } \\
15-30 \%\end{array}$ & $\begin{array}{c}40 \% \text { and higher, No } \\
\text { limit }\end{array}$ & $\begin{array}{l}\text { After gross split with } \\
50 \% \text { limit }\end{array}$ & $\begin{array}{l}\text { Cost Recovery by IOC after gross } \\
\text { revenue split stimulates work } \\
\text { efficiency of the contractor }\end{array}$ \\
\hline 4 & Taxation & Multiple taxes and levies & $\begin{array}{c}\text { Single tax, tax } \\
\text { holidays, tax } \\
\text { deduction and TLCF }\end{array}$ & $\begin{array}{l}\text { Taxes (Profit, local, } \\
\text { road use), pipeline } \\
\text { tariff, excise, } \\
\text { mandatory conversion, } \\
\text { TLCF, Tax deduction }\end{array}$ & $\begin{array}{l}\text { Fiscal incentive supports contractor } \\
\text { with financial risks. In Indonesian } \\
\text { GSS profit tax is the one and only } \\
\text { tax. But in Russia, considering the } \\
\text { taxation habit, some key taxes are } \\
\text { put in to Russian GSS. }\end{array}$ \\
\hline 5 & Royalties \& FTP & Yes, with no split & $\begin{array}{l}\text { No or yes, with } \\
\text { balanced split }\end{array}$ & $\begin{array}{l}\text { Replaced by gross } \\
\text { revenue split and } \\
\text { Incremental sliding } \\
\text { scale components }\end{array}$ & $\begin{array}{l}\text { Mostly, cost recovery weighs on } \\
\text { HG's take. Therefore, to secure total } \\
\text { take, HG sets } 5-20 \% \text { royalties, } \\
\text { which results in increase of } \\
\text { contractor's burden. }\end{array}$ \\
\hline 6 & $\begin{array}{l}\text { Work } \\
\text { commitment }\end{array}$ & $\begin{array}{c}\text { Tech: Seismic, \& } \\
\text { Drilling Data (exp), } \\
\text { digitalization, EOR } \\
\text { (Dev\&Prod), max site } \\
\text { restoration; Financial: } \\
\text { Full investment } \\
\text { with(out) } \\
\text { reimbursement; } \\
\text { Equipment: high } \\
\text { domestic content, } \\
\text { sufficient number of } \\
\text { wells and platform. HR: } \\
\text { high domestic content } \\
\end{array}$ & $\begin{array}{c}\text { Tech: Seismic data. } \\
\text { Financial: partial } \\
\text { investment with } \\
\text { reimbursement \& } \\
\text { investment credit. } \\
\text { Equipment: minimal } \\
\text { number of wells and } \\
\text { platform. HR: min } \\
\text { domestic content, } \\
\text { sufficient reliable } \\
\text { workers }\end{array}$ & \begin{tabular}{|} 
Tech: Seismic, \& \\
Drilling Data in \\
exploration. Financial: \\
partial or full \\
investment with \\
reimbursement. \\
Domestic content min \\
25\%. Equipment, HR, \\
Tech based on variable \\
and progressive \\
components (sliding \\
scale system).
\end{tabular} & $\begin{array}{l}\text { In gross split, work commitment is } \\
\text { valued not only by reliable seismic } \\
\text { and drilling data and delineation, } \\
\text { but also signature bonus. In dev. \& } \\
\text { prod. phase, incentive components } \\
\text { automatically respond to contractor } \\
\text { work commitment. The stronger the } \\
\text { commitment is made, the more } \\
\text { contractor's take is increased, and } \\
\text { vice versa. }\end{array}$ \\
\hline 7 & Gov participation & $\mathrm{Gov}+\mathrm{NOC}+\mathrm{ROC}+\mathrm{IOC}$ & Gov $+\mathrm{IOC}$ & $\mathrm{Gov}+\mathrm{NOC}+\mathrm{IOC}$ & $\begin{array}{l}\text { In IOC's view, working with many } \\
\text { parties is not preferable due to } \\
\text { different cultures. Though risk can } \\
\text { be spread. In HG's view, } \\
\text { involvement of National \& private } \\
\text { Russian companies makes it easier } \\
\text { to control fraud, balance dominant } \\
\text { power and learn science-tech from } \\
\text { IOC. Overall, collaboration is } \\
\text { needed but with limited players. } \\
\text { NOC's carried through exploration, } \\
\text { has } 15 \% \text { interests. }\end{array}$ \\
\hline 8 & $\begin{array}{l}\text { Conflict } \\
\text { resolution }\end{array}$ & $\begin{array}{l}\text { Arbitration, local } \\
\text { litigation as an } \\
\text { alternative }\end{array}$ & Arbitration & $\begin{array}{c}\text { International } \\
\text { Arbitration, and } \\
\text { International litigation } \\
\text { as alternative }\end{array}$ & $\begin{array}{l}\text { Applying basic principles } \\
\text { (Certainty, Efficiency and } \\
\text { Simplicity), GSS gets rid of many } \\
\text { conflict potentials. But when it } \\
\text { appears, the mechanism of } \\
\text { resolution has to be transparent, } \\
\text { cheap, effective and efficient. }\end{array}$ \\
\hline 9 & DD\&A Rates & $\begin{array}{l}\text { Long period with SLD } \\
\text { scheme }\end{array}$ & $\begin{array}{l}\text { Short period with } \\
\text { DDB scheme }\end{array}$ & $\begin{array}{c}\text { Period CAPEX } \leq 1 / 2 \text { of } \\
\text { WP }(\mathrm{DDB}) ; \mathrm{OPEX} \leq \\
2 / 3 \text { of } \mathrm{WP}(\mathrm{SLD})\end{array}$ & $\begin{array}{l}\text { GSS facilitates contractor to better } \\
\text { amortize its capex \& opex. The } \\
\text { tittle to equip belongs to HG. WP is } \\
\text { working period. }\end{array}$ \\
\hline 10 & Ringfencing & Yes & No & Yes & $\begin{array}{l}\text { HG motivates contractor to do } \\
\text { efficiency in order to maximize its } \\
\text { total take }\end{array}$ \\
\hline 11 & DMO & $\begin{array}{l}\text { Yes, } 25 \% \text {, at specific } \\
\text { lower cost }\end{array}$ & $\begin{array}{c}\text { No DMO or } 25 \% \\
\text { DMO at market cost }\end{array}$ & $\begin{array}{c}\text { Yes, } 25 \% \text {, at market } \\
\text { cost }\end{array}$ & $\begin{array}{l}\text { IOC has already consumer. For HG, } \\
\text { DMO can help fulfill national }\end{array}$ \\
\hline
\end{tabular}




\begin{tabular}{|c|c|c|c|c|c|}
\hline Rank & Name & HG & IOC (Contractor) & PSC GS (Optimum) & Note \\
\hline & & & + DMO Fee & & demand as well as activate refinery. \\
\hline 12 & Bonus payments & $\begin{array}{c}\text { Signature and } \\
\text { production Bonus }\end{array}$ & Ministerial & $\begin{array}{l}\text { Signature, prod and } \\
\text { ministerial (sliding } \\
\text { scale) }\end{array}$ & $\begin{array}{l}\text { Production bonuses to } \mathrm{HG} \text { is } \\
\text { regulated in progressive component } \\
\text { with sliding scale approach. While } \\
\text { ministerial bonuses to contractor } \\
\text { depends not only on uneconomic } \\
\text { condition, but also commitment to } \\
\text { efficiency }\end{array}$ \\
\hline 13 & Relinquishment & $\begin{array}{l}\text { No extension of } \\
\text { exploration and dev } \\
\text { phase, surrender full } \\
\text { territory }\end{array}$ & $\begin{array}{c}\text { Extension of } \\
\text { exploration, transfer } \\
\text { or surrender part of } \\
\text { territory }\end{array}$ & $\begin{array}{c}\text { Possible extension of } \\
\text { exploration }\end{array}$ & $\begin{array}{l}\text { Government will decide whether or } \\
\text { not extension is worthy to be } \\
\text { granted. HG considers contractor } \\
\text { commitments to seismic \& drilling } \\
\text { data, \& appraisal) }\end{array}$ \\
\hline 14 & $\begin{array}{c}\text { Investment credit } \\
\& \text { uplifts }\end{array}$ & No & Yes, $5-20 \%$ & $\begin{array}{l}\text { Replaced by sliding } \\
\text { scale components }\end{array}$ & $\begin{array}{l}\text { Such an incentive has been } \\
\text { represented by variable and } \\
\text { progressive components }\end{array}$ \\
\hline 15 & Insurance & $\begin{array}{c}\text { Regulated based on strict } \\
\text { HG's supervision }\end{array}$ & $\begin{array}{l}\text { No regulation (free } \\
\text { to determine) }\end{array}$ & $\begin{array}{c}\text { Regulated: Determined } \\
\text { based on white list }\end{array}$ & $\begin{array}{l}\text { Contractors and subcontractor are } \\
\text { obliged to be adequately insured in } \\
\text { reputable companies written on the } \\
\text { white list }\end{array}$ \\
\hline 16 & $\begin{array}{l}\text { Ownership } \\
\text { transfer }\end{array}$ & No & Yes & $\begin{array}{c}\text { Partially in the form of } \\
\text { participation, not } \\
\text { ownership }\end{array}$ & $\begin{array}{l}\text { Ownership } \\
\text { Contractor can transfer not the } \\
\text { ownership, but participation } \\
\text { interests. }\end{array}$ \\
\hline
\end{tabular}

It also provides optimum requirements in the form of PSC GS. As it can be seen from table 2, PSC GS allows HG and IOC to come to an understanding and to identify common goals in running the collaborative projects. In addition, what will be given special attention is described in notes. Changing the ratio of costs and potential benefits when applying the PSA will significantly increase commercial, budgetary, technological and scientific efficiency (figure 2.)

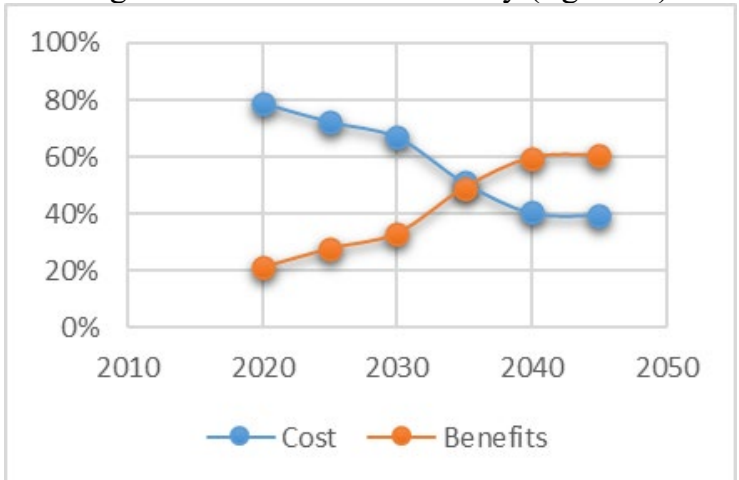

Figure 2. The balance of costs and benefits of a project enable SRP on the Russian shelf (forecast) - compiled by the authors

Based on the table, commerciality, product sharing, cost recovery, taxation, and royalties are key elements in the contract. Therefore, all parties will focus negotiating the terms and conditions for these elements. However, all elements play crucial roles in the contract. For instance, $25 \%$ uplift and ownership transfer can significantly benefit IOC, although 5 above elements belong to $\mathrm{HG}$.

\section{Conclusion}

To sum up, using both analyzes can prepare negotiation participants with the picture of PSC elements, sensitivities, and their interactions; improve mutual understanding in setting goals; and reduce potential disputes. Thus, all parties are able to save the time of signing contracts, minimize costs at further stages of running project, and achieve win-win solution. As we've known, disputes and renegotiation are timeconsuming, costly, and sometimes manipulative. In addition, the cross-analysis gave results in terms of improving project efficiency by $14.7 \%$ for the studied objects of the Arctic and Sakhalin. Thus, the decision to include the PSA synthesis model in the framework of forecast projects for the development of the continental shelf may become promising in terms of commercial efficiency. It will also present an opportunity to improve the scientific and technical potential of the oil and gas industry not only in Russia but also in other countries on the world energy market.

\section{Acknowledgments}

The study was carried out within the framework of RFBR grants 19-07-00455 and 20-04-60185.

\section{Reference}

[1] Kiat M.I., Ilyukhin S.I., Ozdoeva A.Kh. "Indonesian PSC with Gross Split Scheme as an Alternative for offshore business." World Energy: Competition and Cooperation. Ed. S.V. Zhukov, (Moscow: IMEMO RAN, 2019), 48-57, https://www.imemo.ru/files/File/ru/publ/2019/2019 06.pdf

[2] Konoplyanik A.A. "Russian law about PSC." In Overview of the economic situation of Europe, 156-161. New York and Geneva: United Nation, 1998.

[3] Gubanov D.A., Korgin N.A., Novikov D.A., Raikov A.N. Network expertise $2^{\text {nd }}$ edition., 25-43. Moscow: Egves, 2011.

[4] Avdeeva Z., Kovriga S. (2008). Cognitive Approach in Simulation and Control. Proceedings 
of the $17^{\text {th }}$ World Congress The International Federation of Automatic Control, Seoul, Korea, July 6-11, 2008. pp. 1613-1620

[5] Cooper R., Sawaf A. (2000). Executive EQ. Emotional Intelligence in Business. - London, NY: Texere. 2000. - $358 \mathrm{p}$.

[6] Gigerenzer G. (2007). Gut Filling. The Intelligence of the Unconscious. - London: Viking. 2007, 280 p.

[7] Hollender J., Breen B. (2010). The responsibility Revolution. How the Next Generation of Businesses Will Win. - San Francisco. JosseyBasss. A Wiley Imprint. 2010. - 214 p.

[8] Howe J. (2008). Crowdsourcing. Why the Power of the Crowd Is Driving the Future of Business. - NY: Three Rivers Press. 2008.

[9] Jamsa Kris (2013). Cloud Computing. - Burlington (MA). Jones \& Barlett Learning. 2013. 321 p.

[10] Maximov V. (2001). Maximov V. Cognitive Analysis and Situation Modeling // Proceedings of the $8^{\text {th }}$ IFAC Conference on "Social Stability: The Challenge of Technology Development" (SWIIS' 01). Sept. 27 - 29, Vienna, Austria.

[11] Peitgen H.-O., Richer P.H. (1986). The Beauty of Fractals. Images of Complex Dynamical Systems. Berlin, Heidelberg, NY.: Springer Verlag. 1986.

[12] Perkins D. (2001). The Eureka Effect. The art and Logic of Breakthrough Thinking. - NY - London: W W NORTON\&COMPANY. 2001, 293 p.

[13] Raikov A.N. (2008). Raikov A.N. Convergent Cognitype for Speeding-Up the Strategic Conversation. Proceedings of the $17^{\text {th }}$ World Congress The International Federation of Automatic Control, Seoul, Korea, July 6-11, 2008. pp. 8103-8108.

[14] Raikov A.N. (2009). Convergent control and Decision Support. - Moscow. IKAR, 2009. - 244 p (Russian)

[15] Saaty Thomas L. (1988) The Analytic Hierarchy Process. - Pittsburg.: University of Pittsburg.1988.

[16] Ulyanov S., Panfilov S., Kurawaki, I. and Yazenin A. (2001), "Information analysis of quantum gates for simulation of quantum algorithms on classical computers", Proc. QCC\&M, Kluwer Academic / Plenum Publ., 2001, pp. 207-214.

[17] Ulyanov S.V., Raikov A.N. (1998). Chaotic factor in Intelligent Information Decision Support Systems. In: Proc of Third International Conference on Application of Fuzzy Systems and Soft Computing (ICAF'98), Wiesbaden. Germany. October 5-7, pp. 240-245

[18] Wong P.C., Leung L.R. Scott M.J., Mackey P., Foot H., Jr. Taylor Z.T., Xu J. Unwin, S.D., Sanfilippo A. (2009). Designing a Collaborative Visual Analytics Tool for Social and Technological Chang Prediction. In: IEEE Computer Graphics and Application "Collaborative Visualization", September/October 2009. pp. 58-68.

[19] Johnston, D. International petroleum fiscal systems and production sharing contracts, 25-93. Tulsa, Oklahoma: PennWell, 1994.

\section{About the authors}

Kiat Mukhammad I., scientific researcher, National Research University of Oil and Gas n.a. I.M. Gubkin, Moscow, Russia. E-mail: Muhammadiksankiat95@gmail.com Ilyukhin Savelii I., scientific researcher, National Research University of Oil and Gas n.a. I.M. Gubkin, Moscow, Russia. E-mail: savelykh@yandex.ru

Ozdoeva Alina Kh., PhD in economics., scientific researcher, National Research University of Oil and Gas n.a. I.M. Gubkin, Moscow, Russia. E-mail: 4305@bk.ru 